Artikel Penelitian

\title{
Efektivitas Kurma (Phoenix Dactylifera) Dalam Menurunkan Kadar Hba1c Pada Pasien Diabetes Mellitus Tipe 2: Laporan Kasus Berbasis Bukti
}

\author{
Muhammad Sobri Maulana ${ }^{1}$ \\ ${ }^{1}$ Profesi Dokter Pendidikan Dokter, Fakultas Kedokteran Universitas Indonesia, Jakarta \\ Email: Muhammadsobrimaulana31@gmail.com Telpon 081395203503
}

\begin{abstract}
Abstrak: Diabetes Melitus Tipe 2 atau DM Tipe 2 merupakan penyakit metabolik yang dapat menimbulkan berbagai komplikasi berat sehingga diperlukan pengendalian adekuat yang salah satu sasarannya mencakup penurunan kadar HbA1c. Sampai saat ini, pemberian terapi untuk DM Tipe 2 dari golongan obat dan suntik. Terapi herbal seperti kurma (Phoenix dactylifera) masih terbatas dan belum digunakan secara luas meskipun kurma diketahui memiliki efek antihiperglikemia. Mengetahui efektivitas Kurma (Phoenix dactylifera) dalam menurunkan kadar HbA1c pada pasien Diabetes Melitus Tipe 2. Pencarian literature dilakukan pada empat database internet yaitu Pubmed, Scopus, EBSCO dan Cohcrane Library berdasarkan kriteria inklusi dan ekslusi. Berdasarkan hasil telaah kritis didapatkan tujuh studi yang menunjukkan terdapat efektivitas pemberian Kurma (Phoenix dactylifera) pada pasien diabetes mellitus tipe 2 dalam menurunkan kadar HbA1c dan didapatkan hasil restriksi diet kurma yang diperlukan pada pasien diabetes mellitus tipe 2 yang terkontrol tanpa komplikasi sebanyak 3 buah kurma setiap hari yang bermakna secara statistik dengan nilai NNT 1. Pemberian Kurma (Phoenix dactylifera) dapat berguna sebagai terapi tambahan pada pasien Diabetes mellitus tipe 2 karena memiliki efek antihiperglikemia yang dapat menurunkan $0,6 \%$ kadar HbA1c dalam darah.
\end{abstract}

Kata Kunci: Kurma, Phoenix dactylifera, diabetes mellitus tipe 2, HbAlc

Abstract: Type 2 Diabetes Mellitus or Type 2 DM is a metabolic disease that can cause severe complications so that adequate management which one of the targets is lowering HbAlc level is needed. Up to this time, treatment for Type 2 DM including antihiperglycemic and injection. Herbal remedies as well as dates (Phoenix datcylifera) has been limited even though it has well-known antihyperglycemic effect. To investigate the effectivity of Dates (Phoenix dactylifera) in lowering HbAlc level among Type 2 Diabetes Mellitus patients. Literature searching was conducted on four online databases which are PubMed, Scopus, EBSCO, and Cochrane Library based on inclusion and exclusion criterias. Based on the results of critical studies, seven studies have shown that there is effectiveness in the administration of Dates (Phoenix dactylifera) in patients with type 2 diabetes mellitus on Lowering HbAlc levels and restricition of date diet needed for type 2 diabetes mellitus patients in 3 dates per day that are statistically significant for lowering HbAlc level with value of NNT is 1. Administration of Dates (Phoenix dactylifera) can be used as an adjuvant therapy on Type 2 Diabetes mellitus patients because it has antihyperglycemic effect that can reduce $0.6 \%$ of HbAlc level in blood.

Keyword: Dates, Phoenix dactylifera, Type 2 Diabetes Mellitus, HbAlc 


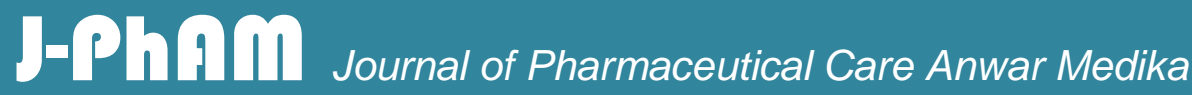

\section{Artikel Penelitian}

\section{PENDAHULUAN}

Diabetes melitus tipe 2 merupakan penyakit metabolik dengan karakteristik hiperglikemia dan patofisiologi kerusakan sentral berupa resistensi insulin pada otot dan liver serta kegagalan sel beta pankreas. Secara garis besar terdapat 8 organ yang berperan dalam patogenesis diabetes melitus tipe 2 adalah kegagalan sel beta pankreas, liver, otot, sel lemak, usus, sel alpa pankreas, ginjal dan otak (ominous octet) dengan mekanisme peningkatan lipolisis, defisiensi incretin, hiperglukagonemia, peningkatan absorpsi glukosa, dan resistensi insulin. ${ }^{1,2}$

Pada tahun 2015, Indonesia menempati peringkat ketujuh di dunia untuk prevalensi diabetes tertinggi di dunia dengan angka prevalensi sebesar 6,9\% pada tahun 2013. DM Tipe 2 dengan komplikasi merupakan penyebab kematian tertinggi ketiga di Indonesia setelah stroke dan penyakit jantung koroner. Saat ini, salah satu kriteria diagnosis DM tipe 2 yang dapat digunakan adalah pemeriksaan $\mathrm{HbAlc} \geq 6,5 \%$ dengan menggunakan metode yang terstandardisasi oleh National Glycohaemoglobin Standarization Program (NGSP). Tujuan jangka panjang pengendalian DM tipe 2 adalah mencegah dan menghambat progresivitas komplikasi mikroangiopati dan makroangiopati seperti retinopati diabetik, kaki diabetik, dan nefropati diabetik. Untuk mencapai tujuan tersebut, diperlukan pengendalian DM yang mencakup lima pilar yaitu edukasi, terapi gizi medis, pelatihan jasmani, intervensi farmakologis dan SMBG (Self Monitoring of Blood Glucose). ${ }^{1}$

Kriteria pengendalian DM didasarkan pada hasil pemeriksaan kadar glukosa, kadar $\mathrm{HbA1c}$, dan profil lipid. Kriteria keberhasilan pengendalian DM salah satunya adalah tercapainya kadar $\mathrm{HbAlc}<7 \%$, selain parameter lainnya seperti Indeks Massa Tubuh, tekanan darah, glukosa darah preprandial kapiler, kolesterol LDL dan HDL, serta trigliserida. Pemeriksaan HbA1c (hemoglobin terglikosilasi atau glikohemoglobin) merupakan indeks kontrol glikemik jangka panjang karena dapat menilai efek perubahan terapi 2-3 bulan sebelumnya. ${ }^{1,2}$ 


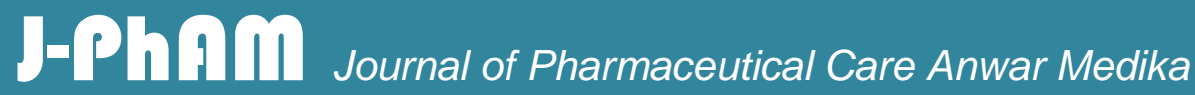

\section{Artikel Penelitian}

Sampai saat ini, terapi farmakologis definitif yang digunakan secara luas untuk DM tipe 2 masih terbatas pada obat-obatan antihiperglikemia suntik dan oral seperti golongan sulfonilurea, glinid, biguanid seperti metformin, penghambat glukosidase alfa, DPP 4inhibitor, dan insulin yang yang masing-masing memiliki efek samping tersendiri. Pengobatan alternatif yang menggunakan bahan baku herbal seperti kurma (Phoenix dactylifera) masih belum digunakan secara luas meskipun sudah banyak studi yang menyimpulkan bahwa selain memiliki berbagai macam efek seperti anti- inflamasi, antioksidan, antibakterial, antiviral, antiparasitik, gastroprotektif, hepatoprotektif, dan antihiperlipidemia, Phoenix dactylifera juga memiliki efek antihiperglikemia namun tidak menimbulkan efek samping yang bermakna seperti obat-obatan antihiperglikemia oral dan suntik yang sudah ada. Phoenix dactylifera merupakan bahan alami yang sejak lama digunakan untuk pengobatan tradisional berbagai penyakit seperti diare, asma, penyakit kulit, dan hipertensi. Saat ini, banyak peneliti melakukan studi terbaru yang melibatkan Phoenix dactylifera sebagai intervensi dalam pengobatan DM tipe 2. ${ }^{1-3}$

\section{Ilustrasi Kasus}

Pasien perempuan Ny. EEM 54 tahun datang dengan keluhan lemas semakin memberat 6 jam sebelum masuk rumah sakit. Lemas yang dirasakan sejak pagi disertai gemetaran diseluruh tubuh dan tidak bertenaga. Pasien sebelumnya merasa menggigil sejak pagi. Keluhan muntah darah, batuk darah disangkal. Pasien didiagnosis hipertensi dan diabetes mellitus (DM) tipe 2 sejak 15 tahun yang lalu, saat itu pasien mengaku mengalami keluhan sering kencing, cepat haus, cepat lapar dan merasa ada penurunan berat badan namun tidak diukur saat itu. Riwayat mengonsumsi jamu-jamuan setiap hari ada selama 1 tahun terakhir meskipun tidak ada keluhan pegal linu. Pasien mengonsumsi obat DM yaitu glibenklamid yang diminum 1 kali sehari. Pasien mengaku rutin meminum obat DM dan hipertensi namun tidak ingat nama obat hipertensi. Pada pemeriksaan fisis, ditemukan pasien compos mentis, tekanan darah 90/60 mmHg, tampak sakit sedang, status gizi sedang, konjungtiva pucat, dan terdapat nyeri tekan pada regio epigastrium. 


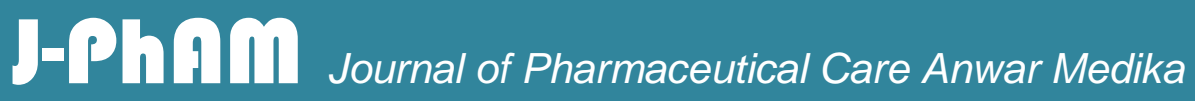

Artikel Penelitian

Pada pemeriksaan penunjang didapatkan $\mathrm{Hb} 8,1$, Leukosit 37900, Ht 25\%, Trombosit 517.000, GDS 147, Ur/CR 129/3,2, Na/Cl/K 135/97/5,2. Pasien diberikan glucovance $250 \mathrm{mg}$ dan cefadroxil 500 gr. Pasien didiagnosis dengan anemia, diabetes melitus tipe 2 obesitas tipe 1 tidak terkontrol tanpa komplikasi, hipertensi grade 1 terkontrol dan Acute Kidney Injury on Chronic Kidney Disease. Pasien dan adik pasien keberatan apabila pasien harus menggunakan obat untuk mengatasi penyakitnya dan bertanya apakah terdapat obat-obatan herbal yang dapat digunakan untuk mengontrol penyakit diabetes melitus yang dideritanya karena pasien pernah mendengar dari tetangganya bahwa kurma dapat digunakan untuk pengobatan diabetes melitus.

\subsection{Pertanyaan Klinis}

Berdasarkan uraian latar belakang dan ilustrasi kasus di atas, disusun pertanyaan klinis sebagai berikut:

“Pada pasien Diabetes Melitus Tipe 2, bagaimana efektivitas kurma (Phoenix dactylifera) dalam menurunkan kadar HbAlc?"

Tabel 1. Formulasi Pertanyaan Klinis

\begin{tabular}{lllll}
\hline \multicolumn{1}{c}{$\begin{array}{c}\text { Patient/Problem } \\
(\mathbf{P})\end{array}$} & \multicolumn{1}{c}{$\begin{array}{c}\text { Intervention } \\
(\mathbf{I})\end{array}$} & \multicolumn{1}{c}{$\begin{array}{c}\text { Comparison } \\
(\mathbf{C})\end{array}$} & \multicolumn{2}{c}{$\begin{array}{c}\text { Outcome } \\
(\mathbf{O})\end{array}$} \\
\hline Pasien Diabetes Melitus & Kurma (Phoenix \\
Tipe 2 & Tanpa kurma & : & Penurunan & kadar \\
Tipe Pertanyaan Klinis & Terapi & Kontrol & HbA1c & \\
\hline Desain studi & $\begin{array}{l}\text { Randomized Controlled Trial, Systematic Review, Meta- } \\
\text { analysis }\end{array}$ & & & \\
\end{tabular}

\section{BAHAN DAN METODE}

\section{Strategi Pencarian}

Penelusuran literatur telah dilakukan pada tanggal 29 Maret 2019 pada 4 online database ilmiah yaitu PubMed, Scopus, EBSCO, dan Cochrane Library. 


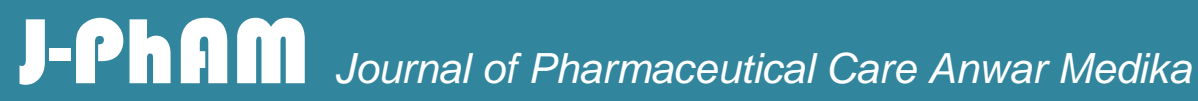

Artikel Penelitian

Kata kunci yang digunakan adalah "type 2 diabetes mellitus", "Phoenix dactylifera" dan "HbA1c" beserta sinonimnya. Kriteria inklusi yang digunakan adalah studi Randomized Controlled Trial (RCT), Meta-analysis, dan Systematic Review, tersedia naskah lengkap/fulltext, dan publikasi dalam bahasa Inggris. Kriteria eksklusi yang digunakan adalah studi pada hewan. Dari proses pencarian dengan kata kunci, didapatkan 82 artikel (Hits) yaitu 10 artikel dari PubMed, 2 artikel dari Scopus, 1 artikel dari EBSCO, dan 1 artikel dari Cochrane Library.

Selanjutnya, artikel diseleksi lebih lanjut berdasarkan kriteria inklusi dan kriteria eksklusi sehingga didapatkan 11 artikel (Article Selected) yaitu 10 artikel dari PubMed dan 1 artikel dari EBSCO.

\section{Seleksi Artikel}

Tahapan selanjutnya adalah skrining artikel berdasarkan kesesuaian judul dan abstrak serta eliminasi artikel ganda. Dari proses tersebut, didapatkan 4 artikel. Selanjutnya, dilakukan pembacaan tiap artikel dan didapatkan 1 Randomized Clinical Trial untuk ditelaah lebih lanjut.

Tabel 2. Temuan Literatur berdasarkan Kata Kunci, Kriteria Inklusi, dan Kriteria Eksklusi

\begin{tabular}{llcc}
\hline Database & \multicolumn{1}{c}{ Kata Kunci } & Hits & $\begin{array}{c}\text { Article } \\
\text { Selected }\end{array}$ \\
\hline Pubmed & $((((($ type 2 diabetes mellitus[Title/Abstract]) OR & 82 & 10 \\
& diabetes[Title/Abstract]) OR & \\
& DMT2[Title/Abstract])) AND ((((Phoenix \\
& dactylifera[Title/Abstract]) OR dates \\
& fruit[Title/Abstract]) OR dates[Title/Abstract] $)$ \\
& OR date palm[Title/Abstract])) AND \\
& $((($ hbA1c[Title/Abstract]) OR \\
& A1c[Title/Abstract]) OR glycated \\
& hemoglobin[Title/Abstract])
\end{tabular}




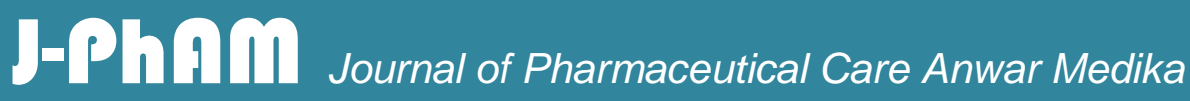

\section{Artikel Penelitian}

\begin{tabular}{llll}
\hline Scopus & (type 2 diabetes mellitus OR type 2 diabetes) & 2 & 1 \\
& AND (Phoenix Dactylifera OR dates fruit) & & \\
& AND & & \\
& (HbA1c OR glycated hemoglobin OR A1c) & & 0 \\
\hline EBSCO & (type 2 diabetes mellitus OR type 2 diabetes) & 1 & \\
& AND (Phoenix Dactylifera OR dates fruit) AND & \\
& (HbA1c OR glycated hemoglobin OR A1c) & \\
\hline Cochrane & $($ type 2 diabetes mellitus OR type 2 diabetes) & \\
Library & AND (Phoenix Dactylifera OR dates fruit) & \\
& AND & & \\
& $($ HbA1c OR glycated hemoglobin OR A1c) & \\
\end{tabular}

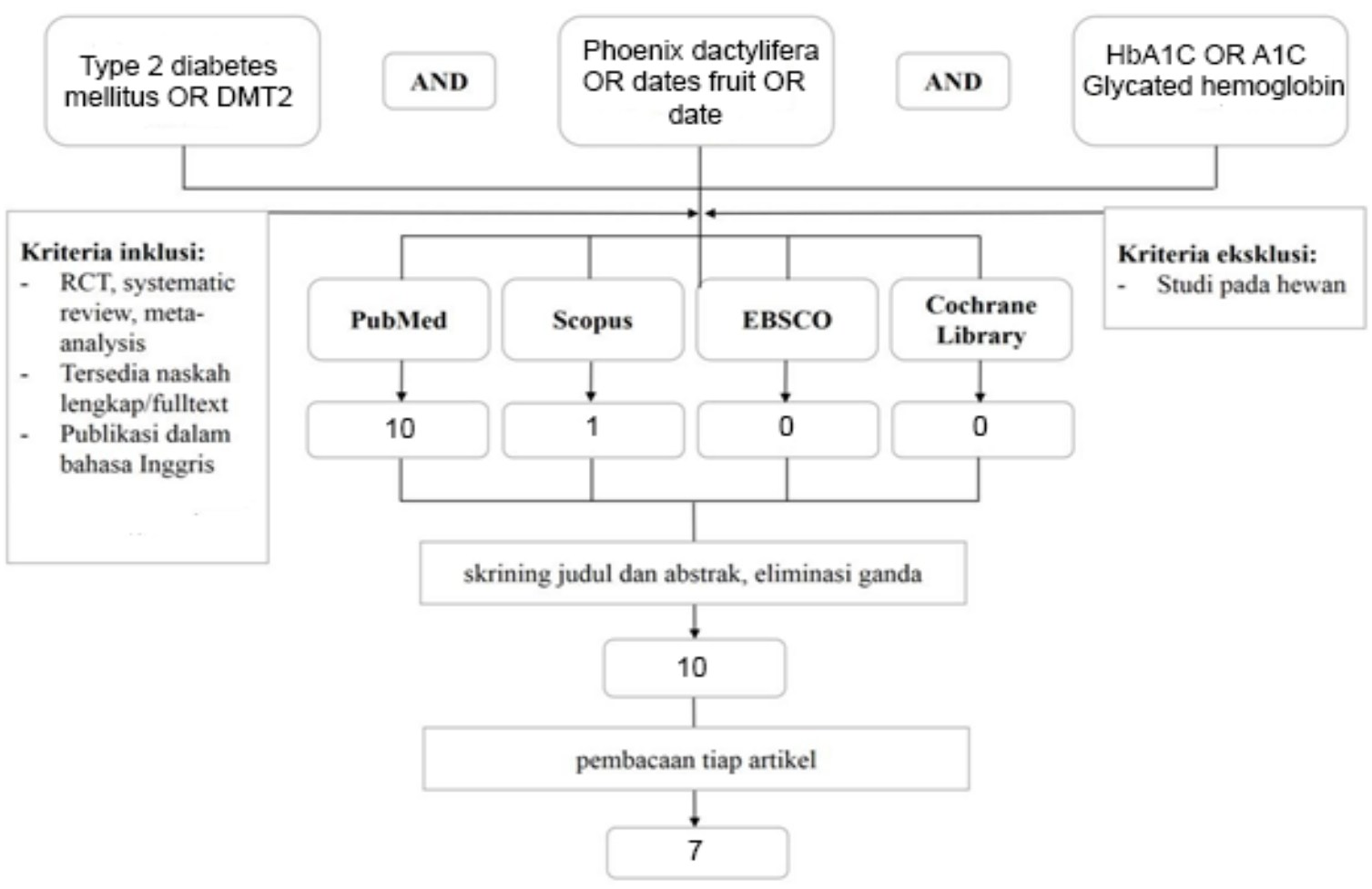

\section{Gambar 1. Alur Pencarian Literatur}




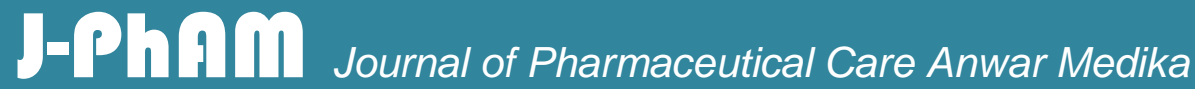

Artikel Penelitian

\subsection{Telaah Kritis}

Dari 7 artikel yang terpilih, dilakukan telaah kritis dengan menggunakan kriteria Oxford Center for Evidence Based Medicine tahun 2011 yang mencakup validitiy, importancy, dan applicability dari jurnal yang masing-masing terpilih.

Artikel Penelitian

\section{HASIL}

\section{Validity, Importance, Applicability}

Peneliti mendapatkan 5 studi randomized controlled trial (RCT) dan 2 studi controlled trial $(C T)$, control trial dengan subjek penelitian pasien Diabetes Melitus tipe 2 yang belum mengalami komplikasi dan tidak menggunakan insulin. Pada studi tersebut dilakukan penilaian validitas studi, kepentingan hasil studi (importance), dan penerapan hasil studi (applicability). Studi yang ditelaah memiliki judul sebagai berikut:

1. Effect of dried fruit on postprandial glycemia: a randomized acute-feeding trial, ditulis oleh Viguilliouk E, Jenkins AL, Mejia SB, Sievenpiper JL, dan Kendall CWC. (2018)

2. Glycemic indices of five varieties of dates in healthy and diabetic subjects, ditulis oleh Alkaabi JM, Al-Dabbagh B, Ahmad S, Saadi HF, Gariballa S, Al-Ghazali M. (2011)

3. Glycemic indices, glycemic load and glycemic response for seventeen varieties of dates grown in Saudi Arabia, ditulis oleh AlGeffari MA, Almogbel ES, Alhomaidan HT, ElMergawi R, Barrimah IA. (2016)

4. The glycaemic index of dates and datelyoghurt mixed meals. Are dates 'the candy that grows on trees'?, ditulis oleh Miller CJ, Dunn EV dan Hashim IB. (2003)

5. Effect of traditional Arabic coffee consumption on the glycemic index of Khalas dates tested in healthy and diabetic subjects, ditulis oleh Alkaabi J, Al-Dabbagh B, Saadi H, Gariballa S, Yasin J. (2013) 


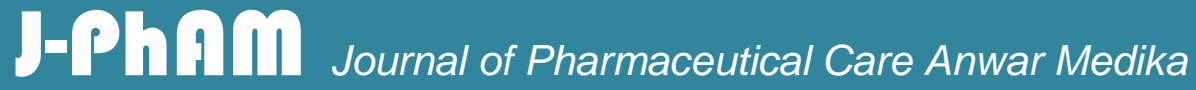

\section{Artikel Penelitian}

6. Comparative responses of plasma glucose, insulin and C-peptide following ingestion of isocaloric glucose, a modified urban Saudi breakfast and dates in normal Saudi persons, ditulis oleh Ahmad M, Al-Othaimeen Am De Vol E, Bold A. (1991)

7. A comparison of acute glycemic and insulin-response to dates (Phoenix-dactylifera) and oral dextrose in diabetic and non diabetic subjects, ditulis oleh Famuyiwa OO, ElHazmi MAF, Al-Jasser SJ, Sulimani RA, Jayakumar RV. (1992)

RCT merupakan salah satu studi yang memiliki kekuatan bukti untuk menjawab pertanyaan klinis yang diajukan. Untuk menilai validitas studi, didasarkan pada perlakuan randomisasi dalam pembagian kelompok dan blinding untuk mengurangi nilai bias, perlakuan yang sama, serta analisis yang dipergunakan pada studi tersebut. Penilaian kepentingan (importance) ditujukan untuk mengetahui besaran efek intervensi (terapi) dan seberapa akurat hasil studi. Penilaian penerapan (applicability) ditujukan untuk mengetahui apakah terapi yang diajukan dapat diterapkan pada kasus yang diangkat dalam laporan berbasis bukti ini.

Tabel 3. Telaah kritis jurnal-jurnal RCT dan CT.

\begin{tabular}{|c|c|c|c|c|c|c|c|c|c|c|c|c|}
\hline & \multicolumn{9}{|c|}{ Validity } & Importance & \multicolumn{2}{|c|}{ Applicability } \\
\hline$\therefore$ & 鯶 & 查 & 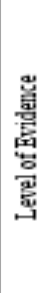 & 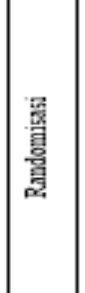 & 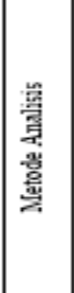 & 買 & 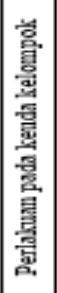 & 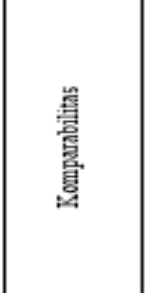 & 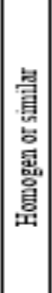 & 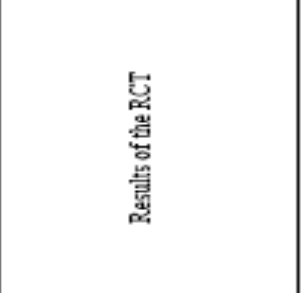 & 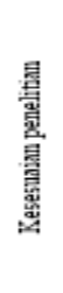 & 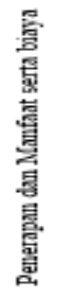 \\
\hline 1 & $\begin{array}{c}\text { Viguilliouk K2 } \\
\text { et al }\end{array}$ & 2018 & 2 & Ya & INT & Ya & $\mathrm{Ya}$ & $18-75$ tahum & $\mathrm{Ya}$ & $\begin{array}{c}\text { NNT }=1 / \text { ARR }=2 h \\
0.375=2.6\end{array}$ & $\mathrm{Ya}$ & $\mathrm{Ya}$ \\
\hline 2 & $\begin{array}{c}\text { Alkabi JM et } \\
\text { al }\end{array}$ & 2011 & 2 & Tidals & $\mathrm{NNT}$ & $\mathrm{Ya}$ & $\mathrm{Ya}$ & 40 tahun & $\mathrm{Ya}$ & $\begin{array}{c}\text { NNT = I/ARR }=1 / 0.06 \\
=16.6\end{array}$ & $\mathrm{Ya}$ & $\mathrm{Ya}$ \\
\hline 3 & $\begin{array}{c}D \text { AlGeffari eq } \\
\text { al }\end{array}$ & 2016 & 2 & Tidala & $\mathrm{INT}$ & Tidals & $\mathrm{Ya}$ & $>31$ tahun & $\mathrm{Ya}$ & $\begin{array}{c}\mathrm{NNT}=1 / \text { ARR }=1 / 0.29 \\
=3.44\end{array}$ & $\mathrm{Ya}$ & $\mathrm{Ya}$ \\
\hline 4 & Miller CJ & 2003 & 2 & $\mathrm{Ya}$ & INT & Tidalas & $\mathrm{Ya}$ & $32-67$ tahum & $\mathrm{Ya}$ & $\begin{array}{c}\text { NNT }=1 / \text { ARR }=\omega h \\
0.045=22.2\end{array}$ & $\mathrm{Ya}$ & $\mathrm{Ya}$ \\
\hline 5 & $\begin{array}{c}\text { Alkaabi Inet } \\
\text { al }\end{array}$ & 2013 & 2 & Ya & INT & Tidals & $\mathrm{Ya}$ & $24-46$ tahur & $\mathrm{Ya}$ & $\begin{array}{c}\text { NNT }=1 / \text { ARR }=1 / 0.27 \\
=3.7\end{array}$ & $\mathrm{Ya}$ & $\mathrm{Ya}$ \\
\hline 6 & $\begin{array}{c}\text { Ahmed M, et } \\
\text { al }\end{array}$ & 1991 & 2 & $\mathrm{Ya}$ & INT & Tidala & $\mathrm{Ya}$ & $29-50$ tahur & $\mathrm{Ya}$ & $\begin{array}{c}\text { NNT }=1 / \text { ARR }=1 / 0.27 \\
=1.1\end{array}$ & $\mathrm{Ya}$ & $\mathrm{Ya}$ \\
\hline 3 & $\begin{array}{l}\text { Famuyiwa } \\
\text { Oo, et al }\end{array}$ & 1992 & 2 & $\mathrm{Ya}$ & INT & Tidals & $\mathrm{Ya}$ & $19-50$ tahur & $\mathrm{Ya}$ & NNT $=1 / A R R=1 / 1=1$ & Ya & $\mathrm{Ya}$ \\
\hline
\end{tabular}




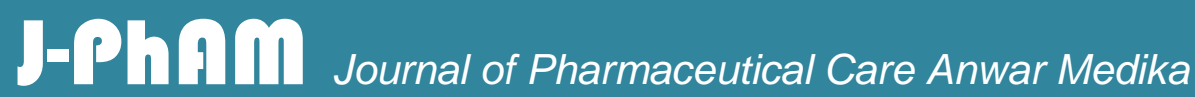

\section{Artikel Penelitian}

\section{PEMBAHASAN}

Diabetes melitus tipe 2 merupakan penyakit yang ditandai dengan hiperglikemia dengan patofisiologi kerusakan sentral berupa resistensi insulin pada otot dan liver serta kegagalan sel beta pankreas. ${ }^{1}$ Terdapat studi yang membahas mekanisme kerja sebagai kandungan dari Kurma. Kurma termasuk dalam golongan dari kelas monokotiledon, subklas Areciae dan family dari Arecaceae. Tanaman ini berasal dari Persia dan India Barat. Buah kurma mengandung karbohidrat, serat tumbuhan, vitamin, protein, lemak dan mineral esensial. Beberapa penelitian melaporkan bahwa kurma memiliki efek sebagai antioksidan, antimutagenik, antimikroba, antiinflamasi, gastroprotektif, hepatoprotektif, nefroprotektif, antikanker dan memiliki efek imunostimulan. Kerusakan vaskuler pada pengidap diabetes mellitus dapat dipicu oleh radikal bebas yang dapat dilawan dengan antioksidan. Kurma terbagi menjadi 3 jenis yaitu kurma muda, ruthab dan tamer. Berdasarkan berbagai jenis tingkat kematangannya, buah kurma sendiri memiliki kandungan antioksidan 13 glikosida-glikosida flavonoid antara lain luteolin, quercetin dan apigenin. Selain itu kurma juga mengandung procyanidin, fenolik, p-coumaric, asam ferulic, asam sinapic dan derivate asam cinnamic. Kurma memiliki serat tidak larut yang dapat menurunkan kadar glukosa dan kolesterol darah. ${ }^{4}$ Kurma sendiri memiliki kalori sebanyak 23 kkal dengan lemak 0,03 gram. Batasan restriksi diet kurma pada pasien diabetes mellitus dianjurkan 2-3 kurma per hari apabila diabetes pada pasien belum mengalami komplikasi dan terkontrol. ${ }^{5}$ Studi yang ditelaah adalah 5 jurnal Randomized Controlled Trial dan 2 Controlled Trial yang membandingkan efek Kurma salah satunya kurma pada pasien DM tipe-2. Tujuan studi tersebut adalah menentukan apakah diet kurma dapat menurunkan kadar HbA1c yang lebih baik dibandingkan tanpa diet kurma ataupun dengan diet lainnya. Parameter yang digunakan ialah penurunan kadar HbA1c. Studi yang dilakukan oleh Viguiliouk E et al (2018) memiliki jumlah penelitian sebanyak 10 orang dengan jumlah 7 laki-laki dan 3 perempuan. Artikel tersebut menggunakan randomisasi dalam menentukan kelompok perlakuan dan kelompok kontrol. 


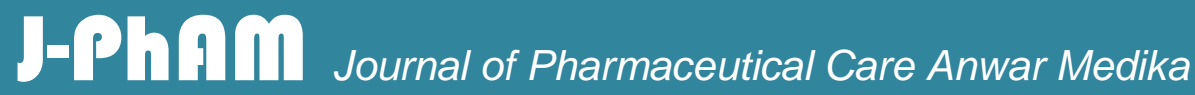

\section{Artikel Penelitian}

Studi tersebut melakukan blinding sehingga peneliti dan subjek penelitian tidak mengetahui perlakuan yang diberikan. Berdasarkan penilaian validitas studi, studi tersebut merupakan studi yang valid untuk menjawab pertanyaan klinis yang telah diajukan.

Dengan diet kurma diharapkan terjadi penurunan kadar HbA1c yang lebih baik jika dibandingkan dengan diet tanpa kurma sehingga membantu mengendalikan DM. Pada studi yang dilakukan oleh Viguiliouk E et al, ${ }^{6}$ penelitian tersebut menunjukkan penurunan kadar HbA1c dengan rata-rata $\geq 0,6 \%$, Kemungkinan keuntungan yang akan didapatkan oleh pasien setelah melakukan diet kurma dinilai dengan Number Needed to Treat (NNT). Jika nilai NNT mendekati angka satu, dianggap kualitas terapi yang diujikan semakin baik. Pada studi yang dilakukan oleh Viguiliouk E et al, didapatkan nilai NNT 2.

Studi yang dilakukan oleh Alkaabi JM E et al (2011) memiliki jumlah penelitian sebanyak 23 orang dengan 13 orang penderita diabetes dan 10 orang tanpa diabetes. Artikel tersebut tidak menggunakan randomisasi dalam menentukan kelompok perlakuan dan kelompok kontrol. Studi tersebut melakukan blinding dengan menggunakan computer sehingga peneliti dan subjek penelitian tidak mengetahui perlakuan yang diberikan. Perlakuan yang dilakukan sama dengan komparabel karakteristik kelompok pada usia diatas 40 tahun. Berdasarkan penilaian validitas studi, studi tersebut merupakan studi yang valid untuk menjawab pertanyaan klinis yang telah diajukan. Dengan diet kurma diharapkan terjadi penurunan kadar $\mathrm{HbA1c}$ baik untuk pasien diabetes maupun tanpa diabetes sehingga membantu mengendalikan DM. Pada studi yang dilakukan oleh Alkaabi $\mathrm{JM}$ et al, ${ }^{7}$ penelitian tersebut menunjukkan penurunan kadar HbA1c dengan rata-rata < 0,6\% dengan NNT 16.6. Hal tersebut menunjukkan bahwa terdapat signifikan penurunan HbA1c pada pasien diabetes. Meskipun pada artikel tersebut membatasi kurma dengan jumlah dan jenis kurma. Jenis kurma yang dianjurkan pada artikel Alkaabi JM et al adalah untuk mengonsumsi kurma tipe Tamer. Kurma tipe tamer merupakan kurma basah yang pada penelitian tersebut dipakai dalam penelitian untuk menurunkan $\mathrm{HbA} 1 \mathrm{c}$ pada pasien diabetes dan terdapat efek postprandial glukosa. 


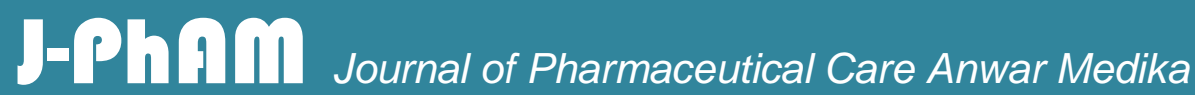

\section{Artikel Penelitian}

Studi yang dilakukan oleh AlGeffari et al (2016) memiliki jumlah penelitian sebanyak 19 partisipan dengan perlakuan 10 partisipan mendapatkan kurma tipe tamer dan 9 partisipan mendapatkan 50 gr glukosa. Artikel tersebut tidak menggunakan randomisasi dalam menentukan kelompok perlakuan (kurma tipe tamer) dan kelompok control (50 gr glukosa). Studi tersebut tidak melakukan blinding sehingga peneliti dan subjek penelitian mengetahui perlakuan yang diberikan. Perlakuan yang dilakukan sama dengan komparabel karakteristik kelompok pada usia rerata diatas 30 tahun. Berdasarkan penilaian validitas studi, studi tersebut merupakan studi yang valid untuk menjawab pertanyaan klinis yang telah diajukan. Dengan diet kurma diharapkan terjadi penurunan kadar HbA1c dengan indikator glikemik indeks dan muatan glikemik. Pada perlakuan kurma tipe tamer didapatkan hasil peningkatan glukosa pada 4 partisipan dengan peningkatan $\mathrm{HbA1c}$ sekitar $0.2 \%$ sedangkan pada 6 partisipan diketahui tidak ada peningkatan HbA1c namun terdapat penurunan $1 \%$ muatan glikemik. Sedangkan pada perlakuan 9 partisipan dengan 50 gr glukosa didapatkan peningkatan HbA1c yang meningkat sebanyak 3\% pada glikemik indeks. Hal tersebut menunjukkan bahwa kurma dapat menurunkan HbA1c sehingga membantu mengendalikan DM. Pada studi yang dilakukan oleh AlGeffari et al, ${ }^{8}$ penelitian tersebut menunjukkan penurunan kadar HbA1c dengan menggunakan indikator glikemik indeks dan muatan glikemik. dengan NNT 3.44. Hal tersebut dapat menjadi landasan bahwa terdapat signifikan penurunan HbA1c pada pasien diabetes. Pada penelitian tersebut menunjukkan bahwa kurma tipe kamer dapat menurunkan HbA1c pada partisipan sehat dan penderita diabetes.

Studi yang dilakukan oleh Miller CJ et al (2013) memiliki jumlah penelitian sebanyak 44 partisipan relawan dengan perlakuan 32 partisipan relawan mendapatkan berbagai jenis kurma dan 12 partisipan mendapatkan 50 gr glukosa berupa meal ataupun makanan setempat. Artikel tersebut menggunakan randomisasi dalam menentukan kelompok perlakuan (17 tipe kurma) dan kelompok control (50 gr glukosa berupa meal). Studi tersebut tidak melakukan blinding sehingga peneliti dan subjek penelitian mengetahui perlakuan yang diberikan. 


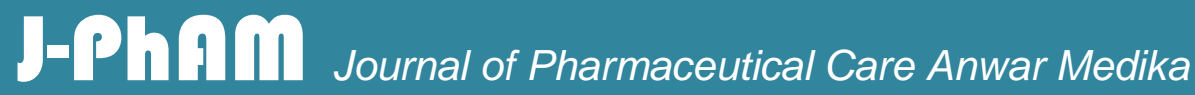

\section{Artikel Penelitian}

Perlakuan yang dilakukan sama dengan komparabel karakteristik kelompok lakilaki dan perempuan pada usia antara 32-67 tahun. Berdasarkan penilaian validitas studi, studi tersebut merupakan studi yang valid untuk menjawab pertanyaan klinis yang telah diajukan. Dengan diet berbagai jenis dan tipe kurma diharapkan terjadi penurunan kadar $\mathrm{HbA1c}$ dengan indikator glikemik indeks dan penurunan $\mathrm{HbA} 1 \mathrm{c}$ sebanyak $<0.6 \%$. Pada studi yang dilakukan oleh Miller CJ et al, ${ }^{9}$ penelitian tersebut menunjukkan penurunan kadar HbA1c dengan menggunakan indikator glikemik indeks dan penurunan HbA1c sebanyak $<0.6 \%$ dengan NNT 22.2. Hal tersebut dapat menjadi landasan bahwa terdapat signifikan penurunan HbA1c pada pasien diabetes. Meskipun pada penelitian tersebut tidak dilakukan medical checkup apakah subjek relawan tersebut menderita diabetes. Pada penelitian tersebut menunjukkan bahwa kurma tipe kamer dapat menurunkan HbA1c.

Studi yang dilakukan oleh Alkaabi J et al (2013) memiliki jumlah penelitian sebanyak 23 partisipan relawan dengan perlakuan 10 partisipan relawan mendapatkan kurma dengan kopi dan 13 partisipan relawan mendapatkan kurma tanpa kopi. Artikel tersebut menggunakan randomisasi dalam menentukan kelompok perlakuan (Kurma tanpa kopi) dan kelompok control (Kurma dengan kopi arab). Studi tersebut tidak melakukan blinding sehingga peneliti dan subjek penelitian mengetahui perlakuan yang diberikan. Perlakuan yang dilakukan sama dengan komparabel karakteristik kelompok laki-laki dan perempuan pada usia antara 26-46 tahun. 13 subjek relawan sehat dengan 10 subjek relawan penderita diabetes. Berdasarkan penilaian validitas studi, studi tersebut merupakan studi yang valid untuk menjawab pertanyaan klinis yang telah diajukan. Dengan diet berbagai kurma tanpa kopi diharapkan terjadi penurunan kadar HbA1c. Pada studi yang dilakukan oleh Alkaabi $\mathrm{J}$ et al, ${ }^{10}$ penelitian tersebut menunjukkan penurunan kadar HbA1c \% dengan NNT 3.7. Meskipun pada penelitian tersebut menggunakan perlakuan pada kopi dengan kurma dan kurma tanpa kopi pada subjek sehat dan subjek penderita diabetes.

Studi yang dilakukan oleh Ahmad M et al (1991) memiliki jumlah penelitian sebanyak 19 subjek penderita diabetes mellitus tipe 2 dibagi 10 subjek mendapatkan 3 buah kurma dan 9 subjek mendapatkan sarapan pagi dengan 300 kalori. 


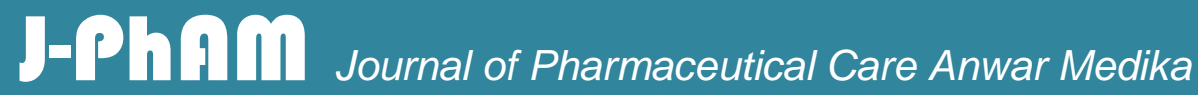

\section{Artikel Penelitian}

Artikel tersebut menggunakan randomisasi dalam menentukan kelompok perlakuan (3 buah kurma) dan kelompok control (sarapan pagi). Studi tersebut tidak melakukan blinding sehingga peneliti dan subjek penelitian mengetahui perlakuan yang diberikan. Perlakuan yang dilakukan sama dengan komparabel karakteristik kelompok laki-laki dan perempuan pada usia antara 29-50 tahun. Total subjek 19 penderita diabetes mellitus dengan 11 lakilaki dan 8 perempuan. Berdasarkan penilaian validitas studi, studi tersebut merupakan studi yang valid untuk menjawab pertanyaan klinis yang telah diajukan. Dengan diet 3 buah kurma diharapkan terjadi penurunan kadar HbA1c. Pada studi yang dilakukan oleh Alkaabi J et al, ${ }^{11}$ penelitian tersebut menunjukkan penurunan kadar HbA1c \% dengan NNT 1.1. Penelitian tersebut dilakukan atas dasar Al-Quran dan Al-Hadis. Penelitian tersebut juga menggunakan sunah rasul yaitu konsumsi 3 buah kurma sangat baik untuk kesehatan. Hal tersebut menjadi landasan dilakukan penelitian tersebut. Pada penelitian tersebut sendiri dilakukan indikator pengukuran dengan menggunakan Gula Darah Sewaktu setelah 2 jam makan kurma dan sarapan pagi. Didapatkan adanya penurunan GDS pada subjek penelitian diabetes yang mendapatkan perlakuan mengonsumsi 3 buah kurma.

Studi yang dilakukan oleh Famuyiwa et al (1992) memiliki jumlah penelitian sebanyak 16 subjek penderita diabetes mellitus tipe 2 dibagi 8 subjek mendapatkan buah kurma dan 8 subjek mendapatkan snack meal. Artikel tersebut menggunakan randomisasi dalam menentukan kelompok perlakuan (buah kurma) dan kelompok control (snack meal). Studi tersebut tidak melakukan blinding sehingga peneliti dan subjek penelitian mengetahui perlakuan yang diberikan. Perlakuan yang dilakukan sama dengan komparabel karakteristik kelompok laki-laki dan perempuan pada usia antara 19-50 tahun. Total subjek 16 penderita diabetes mellitus tipe 2 dengan 7 laki-laki dan 9 perempuan. Berdasarkan penilaian validitas studi, studi tersebut merupakan studi yang valid untuk menjawab pertanyaan klinis yang telah diajukan. Dengan diet buah kurma diharapkan terjadi penurunan kadar HbA1c. Pada studi yang dilakukan oleh Famuyiwa OO et al, ${ }^{12}$ penelitian tersebut menunjukkan penurunan GDS dengan NNT 1.

Dari ketujuh jurnal tersebut menunjukkan bahwa kurma memiliki khasiat dalam pengendalian diabetes mellitus. 


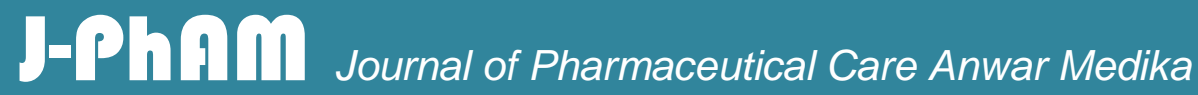

\section{Artikel Penelitian}

Hal ini didasarkan dari penelitian Alkaabi yang menunjukkan bahwa adanya penurunan glukosa dan penurunan $\mathrm{HbA} 1 \mathrm{c}$ sebanyak $0.6 \%$ dari pengonsumsian buah kurma. Ahmad $\mathrm{M}$ et al juga menyarankan restriksi 3 buah kurma setiap hari baik dalam menekan komplikasi dari diabetes mellitus. Secara klinis, karakteristik populasi yang digunakan pada kedua studi sering ditemukan saat praktik di berbagai klinik dan rumah sakit yang berada di Indonesia.

\section{KESIMPULAN DAN SARAN}

Berdasarkan telaah kritis terhadap 1 studi tersebut, disimpulkan bahwa diet kurma dapat menurunkan kadar HbA1c lebih baik pada pasien DM tipe-2. Konsumsi kurma juga memiliki keuntungan berupa penurunan kebutuhan pasien akan terapi farmakologis dan penurunan IMT. Pelaksanaan konsumsi kurma diharapkan dapat memberikan pengendalian terhadap penyakit DM yang lebih baik dan efisien sehingga terjadi peningkatan kualitas hidup

\section{DAFTAR PUSTAKA}

1. Perkumpulan Endokrinologi Indonesia. Konsensus pengelolaan dan pencegahan diabetes melitus tipe 2 di Indonesia 2015. Jakarta: Perkeni; 2015.

2. Jameson, Fauci, Kasper, Hauser, Longo and Loscalzo. Harrison's principles of internal medicine. $20^{\text {th }}$ Ed, New York: McGraw-Hill, Medical Pub. Division; 2018. P 2837903.

3. Daryabeygi-Khotbehsara R, Golzarand M, Ghaffari MP, Djafarian K. Nigella sativa improves glucose homeostasis and serum lipids in type 2 diabetes: A systematic review and meta-analysis. Complementary Therapies in Medicine. 2017; 35(1): 6-13.

4. Tahvilzadeh M, Hajimahmoodi M, Rahimi R. The Role of Date Palm (Phoenix dactylifera L) Pollen in Fertility: A Comprehensive Review of Current Evidence. J Evid Based Complementary Altern Med. 2016 Oct;21(4):320-4 DOI. $10.1177 / 2156587215609851$. 


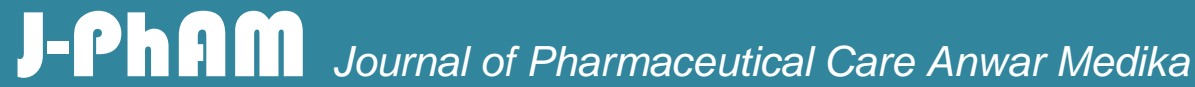

\section{Artikel Penelitian}

5. Al-Farsi MA, Lee CY. Nutritional and functional properties of dates: a review. Crit Rev Food Sci Nutr. 2008;48(10):877-87. doi: 10.1080/10408390701724264

6. Viguilliouk E, Jenkins AL, Mejia SB, Sievenpiper JL, dan Kendall CWC. Effect of dried fruit on postprandial glycemia: a randomized acute-feeding trial. Nutr Diabetes. 2018; 8: 59. DOI. 10/1038/s41387-018-0066-5

7. Alkaabi JM, Al-Dabbagh B, Ahmad S, Saadi HF, Gariballa S, Ghazali MA. Glycemic indices of five varieties of dates in healthy and diabetic subjects. Nutr J. 2011 May 28:10;59. DOI. 10/1186/1475-2591-19-59

8. AlGeffari MA, Almogbel ES, Alhomaidan HT, El-Mergawi R, Barrimah IA. Glycemic indices, glycemic load and glycemic response for seventeen varieties of dates grown in Saudi Arabia. Ann Saudi Med. 2016 Nov-Dec; 36(6): 397-403. DOI.10.5144/02564947.2016.397

9. Miller CJ, Dunn EV, Hashim IB. The glycaemic index of dates and date/yoghurt mixed meals. Are dates 'the candy that grows on trees'? Eur J Clin Nutr. 2003 Mar;57(3):42730.

10. Alkaabi J, Al-Dabbagh B, Saadi H, Gariballa S, Yasin J. Effect of traditional Arabic coffee consumption on the glycemic index of Khalas dates tested in healthy and diabetic subjects. Asia Pac J Clin Nutr. 2013;22(4):565-73. DOI. 10.6133/apjen.2013.22.4.09

11. Ahmed M, Al-Othaimeen A, De VE, Bold A. Comparative responses of plasma glucose, insulin and C-peptide following ingestion of isocaloric glucose, a modified urban Saudi breakfast and dates in normal Saudi persons. Ann Saudi Med. 1991 Jul;11(4):414-7

12. Famuyiwa OO, El-Hazmi MAF, Al-Jasser SJ, Sulimani RA, Jayakumar RV, Al-Nuaim AA, Mekki MO. A Comparison of Acute Glycaemic and Insulin Response to Dates (Phoenix dactylifera) and Oral Dextrose in Diabetic and Non-diabetic Subjects. Saudi Medical Journal. 1992;13(5):397-402 